Aquacultural Engineering

Volume 6, Issue 2, 1987, Pages 141-150

\title{
Approach to biomass production of the marine microalga Tetraselmis suecica (kylin) butch using common garden fertilizer and soil extract as cheap nutrient supply in batch cultures
}

Jaime Fabregas, Luisa Toribio, Julio Abalde, Buenaventura Cabezas, Concepcion Herrero

Departamento de Microbiologia, Facultad de Farmacia, Universidad de Santiago, Santiago de Compostela, Spain

Fabregas J, Toribio L, Abalde J, Cabezas B, Herrero C. Approach to biomass production of the marine microalga tetraselmis suecica (kylin) butch using common garden fertilizer and soil extract as cheap nutrient supply in batch cultures. Aquac Eng 1987;6(2):141-50.

ISSN: 01448609

DOI: 10.1016/0144-8609(87)90011-2 http://dx.doi.org/10.1016/0144-8609(87)90011-2

\begin{abstract}
We report the possibility of an economic cultivation of the marine microalga Tetraselmis suecica, using different mixtures of a common garden fertilizer, soil extract, micronutrients and vitamins. Maximum cellular densities were obtained with a nitrogen concentration of $14 \mu \mathrm{g} / \mathrm{ml}$ and maximum protein concentrations were obtained with 28 $\mu \mathrm{g} \mathrm{N} / \mathrm{ml}$, in all cases. The mixture of fertilizer + soil extract + micronutrients gave the best results for obtaining maximum cellular densities and protein concentrations per $\mathrm{ml}$ of culture. An economic evaluation showed a maximum of $2770 \mathrm{~g}$ of microalgal protein/dollar and $210 \times 10^{12}$ microalgal cells/dollar with the mixture of the fertilizer and soil extract.
\end{abstract}




\section{Introduction}

A great interest in marine micro algal biomass production has been provoked by the artificial cultivation of shellfish in a hatchery environment (Ukeles, 1980). In all types of molluscan aquaculture (research investigations, pilot plants or commercial hatcheries) it is necessary to have a large microalgal biomass available as a source of food for normal development and growth of the cultured species. In fact, production of this biomass is frequently cited as critical to the success of the project and as being a serious impediment to the future development of shellfish aquaculture (De Pauw et al., 1983). The mass culture of certain species of micro algae is considered the major bottleneck in the nursery culturing of molluscs (Persoone and Claus, 1980).

Mass production of micro algae has long been successfully carried out either by using domestic or bio-industrial wastes or inorganic compounds (Shelef and Soeder, 1980; Fabregas et al., 1985a). The culture medium should be nontoxic to larvae, so that the use in larval rearing of waste-supported micro algal biomass is often questionable. Therefore, clean nutrient sources are often used and these media are generally laboratory preparations (Stein, 1973; Soeder, 1980; Fabregas et al., 1984a, 1985 a). Agricultural or common garden fertilizers containing nitrogen and phosphorus have been used as an alternative source of nutrients (Persoone and Claus, 1980; Ukeles, 1980; Gonzalez-Rodriguez and Maestrini, 1984). Such fertilizers are mainly composed of nitrogenous and phosphorous substances and some, if any, micronutrients such as iron, potassium or sodium (Gonzalez-Rodriguez and Maestrini, 1984), but, in general, they do not contain all the micronutrients and vitamins necessary for microalgal growth (Stein, 1973).

The marine microalga Tetraselmis suecica is at present widely used in aquaculture (Walne, 1974; Bayne, 1976; Laing and Utting, 1980) and it has been suggested as a potential source of Single Cell Protein (SCP) (Fabregas and Herrero, 1985). This marine microalga is able to tolerate a wide range of nutrient concentration-salinity conditions (Fabregas et al., 19 84a). The mass production of this microalga with optimum inorganic nutrient concentration has also been achieved (Fabregas et al., $1985 \mathrm{a}, \mathrm{b})$. In this paper, we report the possibility of a more economic cultivation of this micro alga, using a common garden fertilizer, soil extract, micronutrients or vitamins, instead of inorganic nutrients of a defined medium. 


\section{Materials and methods}

The marine microalga used was Tetraselmis suecica, isolated from Ria de Arosa waters (NW Spain). It was cultured in seawater filtered through a 0-45 $\mu \mathrm{m}$ Millipore filter, autoclaved at $120^{\circ} \mathrm{C}$ for $20 \mathrm{~min}$ and enriched with the different nutrients. We used four types of nutrients: common garden fertilizer, Ferticros 7-12-7 (F); common garden fertilizer + soil extract $(F+S E)$; common garden fertilizer + soil extract + micronutrient $(F+S E+M)$; common garden fertilizer + micronutrient + vitamins $(F+M+V)$. As a blank, we used a culture with the inorganic medium commonly used in our laboratory (Fabregas and Herrero, 1985; Fabregas et al., 1984a, 1985a). All the experiments were carried out in triplicate.

The composition of Ferticros 7-12-7 is: nitrogen, 7\%; phosphoric anhydride, $11 \%$; potassium oxide, $7 \%$. This fertilizer constituted the nitrogen and phosphorus source for the microalgal cultures. It was dissoh.ed in distilled water, filtered through a paper filter and autoclaved at $120^{\circ} \mathrm{C}$ for $15 \mathrm{~min}$. We used six different concentrations: 0'05, $0^{\prime} 1$, $0^{\prime} 2,0$, $4,0^{\prime} 8$ and $1^{\prime} 6 \mathrm{mg} / \mathrm{ml}$, giving $3^{\prime} 5,7^{\prime} 0,14^{\prime} 0,28^{\prime} 0,56^{\prime} 0$ and $112^{\prime} 0 \mu \mathrm{g}$ of nitrogen per $\mathrm{ml}$ of culture, respectively.

Soil extract was prepared by mixing 1 volume of soil with 2 volumes of distilled water, filtering through a paper filter and autoclaving at $110^{\circ} \mathrm{C}$ for $20 \mathrm{~min}$ (Stein, 1973). This extract was added to all the cultures at a concentration of $50 \mathrm{ml} / \mathrm{litre}$.

The micronutrients used were: $\mathrm{ZnCl}_{2}, 0$ '136 mg/litre; $\mathrm{MnCl}_{2} .4 \mathrm{H}_{2} \mathrm{O}, 0$ 0'198 mg/litre; $\mathrm{MoO}_{4} \mathrm{Na}_{2}$. $2 \mathrm{H}_{2} \mathrm{O}, 0$ '242 mg/litre; $\mathrm{CoCl}_{3}, 0$ 0165 mg/litre; $\mathrm{CuSO}_{4} .5 \mathrm{H}_{2} \mathrm{O}, 0$ '0249 mg/litre; ferric citrate, 6'7 mg/litre; EDTA, 9'38 mg/litre.

The vitamins used were: thiamine, $35 \mu \mathrm{g} /$ litre; biotin, $5 \mu \mathrm{g} / \mathrm{litre}$; $\mathrm{B}_{12} 3 \mu \mathrm{g} /$ /itre.

The concentrations of soil extract, micronutrients and vitamins were constant in all the experiments. Cultures were carried out in Kimax screw-capped test tubes $(15 \times 2.5 \mathrm{~cm})$ with $25 \mathrm{ml}$ of medium. All cultures were maintained in a controlled environmental incubator (New Brunswick) at $15^{\circ} \mathrm{C}$ in 3900 -lux light from fluorescent lamps (Philips TL 20W/55). A 12 h:12 h light:dark regime was maintained in order to obtain synchronous cultures. An inoculum of $1 \times 10^{4}$ logarithmic-phase cells $/ \mathrm{ml}$ was used.

To obtain the optical density, the transmittance $T$ of the cultures was determined by using a Coleman II 6/20 spectrophotometer reading at $530 \mathrm{~nm}$. 
Cellular density of the cultures was determined by counting culture aliquots in a Thoma chamber. Protein was measured in the stationary phase by the dye-binding method (Bradford, 1976).

Chlorophylls were extracted in acetone:methanol $(2: 1)$ at $4^{\circ} \mathrm{C}$ for $48 \mathrm{~h}$. The extracts were filtered through a Fluoropore Millipore filter for clarification (Fabregas et al., 1984b), and absorbances of the pigment extract at specific wavelengths were recorded. The concentration of chlorophyll a was determined by the formula of Parsons and Strickland (1965).

After the sixth day of Culturing, $\mathrm{CO}_{2}$ was added to the cultures in order to maintain the $\mathrm{pH}$ within the optimum interval (7-4-8'5), at a rate between 02 and $2 \mathrm{ml}$ per tube of culture.

The cultures were not continuously aerated, although $\mathrm{CO}_{2}$ was addeddaily after the sixth day at a rate of $0.2-2 \mathrm{ml}$ per culture. This $\mathrm{CO}_{2}$ supply prevented the carbon source from becoming limiting and at the same time maintained the $\mathrm{pH}$ within the optimum range for $\mathrm{T}$. suecica growth; because of this, the values obtained in the control for cell, protein and chlorophyll a concentrations are greater than those obtained in batch conditions without CO2 supply (Fabregas et al., 1984a).

We plotted optical density, expressed as (100 - T), against time and against nitrogen concentration for each type of nutrient, obtaining threedimensional figures (Fig. 1). We also plotted cellular density against time and against nitrogen concentration for each type of nutrient, again obtaining three-dimensional figures (Fig. 2).

Maximum cellular densities were obtained with a nitrogen concentration of $14 \mu \mathrm{g} / \mathrm{ml}$ of culture medium, with all the different mixtures assayed. Optimum growth can be observed both by optical density measurements (Fig. 1) and by cell counting (Fig. 2). The growth (cells/ ml) was significantly greater with $14 \mu \mathrm{g} / \mathrm{ml}$ of nitrogen than with the other nitrogen concentrations in all cases. However, in cultures with different concentrations of the medium used as controls in these experiments, optimal growth conditions were obtained with nitrogen concentrations higher than $14 \mu \mathrm{g} / \mathrm{rnl}$, not only for T suecica (Fabregas et al., 1984a) but also for other marine microalgae such as Isochrysis galbana (Fabregas et al., 1985b). 

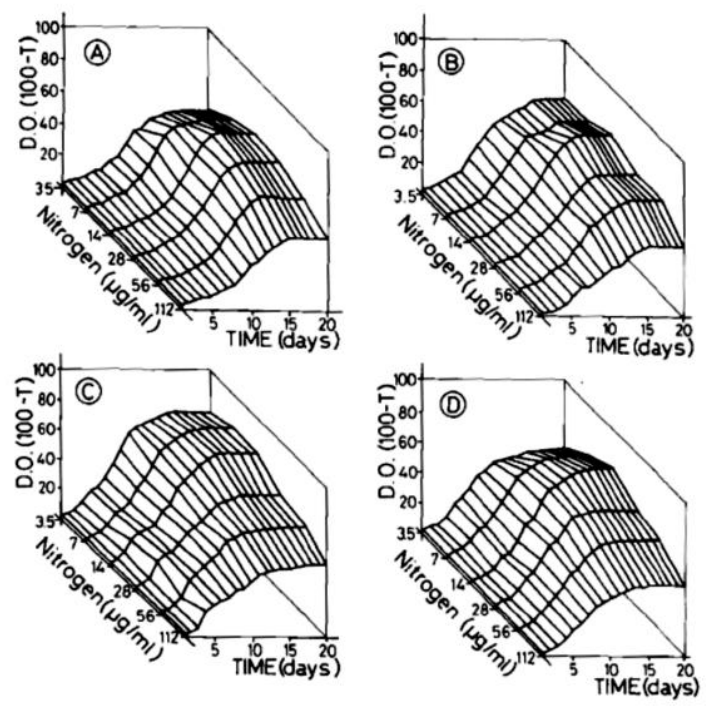

Fig. 1. Growth of cultures of $T$. suecica with different mixtures and concentrations of nutrients: A, fertilizer; B, fertilizer + soil extract; C, fertilizer + soil extract + micronutrients; D, fertilizer + micronutrients + vitamins.
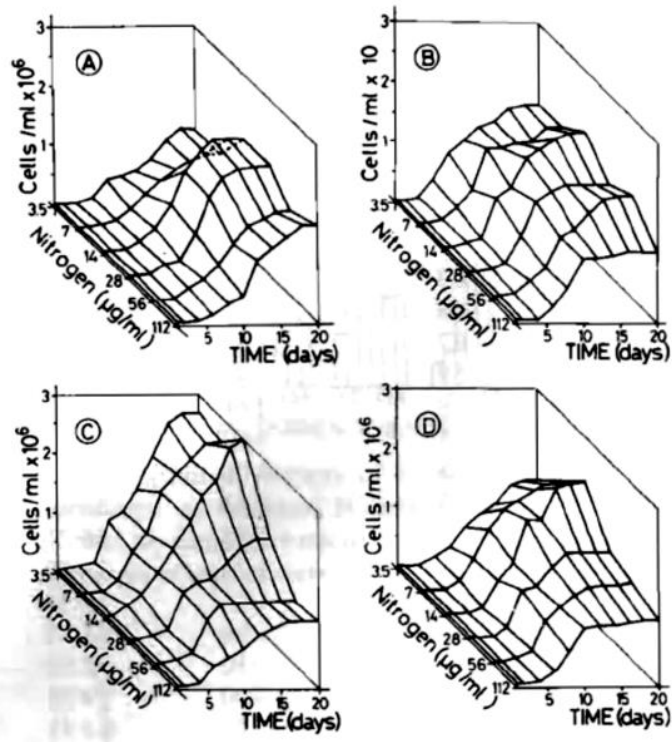

Fig. 2. Cellular densities of cultures of T. suecica with different mixtures and concentrations of nutrients: A, fertilizer; B, fertilizer + soil extract; C, fertilizer + soil extract + micronutrients; D, fertilizer + micronutrients + vitamins.

Maximum cellular density obtained at the stationary phase at this nitrogen concentration was $3 \times 10^{6}$ cells $/ \mathrm{ml}$ for the culture with $\mathrm{F}+\mathrm{SE}+\mathrm{M}$ (Table 1). However, this growth was $54 \%$ less than that of the control with the defined medium, which reached a final biomass at the stationary phase of $5.5 \times 10^{6} \mathrm{cells} / \mathrm{ml}$ (Table 1$)$.

For the same nitrogen concentration, the pattern of maximum cellular density was as follows:

$$
\mathrm{F}+\mathrm{SE}+\mathrm{M}>\mathrm{F}+\mathrm{M}+\mathrm{V}>\mathrm{F}+\mathrm{SE}>\mathrm{F}
$$


Protein concentration is not proportional to cellular density. Maximum protein concentrations were obtained with $28 \mu \mathrm{g} / \mathrm{ml}$ of nitrogen in all experiments (Table 1; Fig. 3), with $64^{\prime} 7 \mu \mathrm{g}$ of protein/rnl in the culture with $\mathrm{F}+\mathrm{SE}+\mathrm{M}$. Protein concentration in the control was $147 \mu \mathrm{g} / \mathrm{ml}, 228 \%$ greater than that of each of the other nutrients.

The chlorophyll a content presented more variation depending on the different concentrations and types of nutrients. In general, maximum values were obtained with nitrogen concentrations of 14, 28 and $56 \mu \mathrm{g} / \mathrm{ml}$ (Table 1; Fig. 4). The maximum value of chlorophyll a was obtained in the cultures with $F+S E+M$, with 4-4 $\mu \mathrm{g} / \mathrm{ml}$. These cultures were the ones with better growth, too. However, this value is $45 \%$ less than that obtained with the control.

Excepting the control, the cultures with $F+S E+M$ showed better growth than the other cultures, and the major protein and chlorophyll a content.

TABLE 1

Growth and Protein and Chlorophyll $a$ Concentrations of Cultures of T. suecica with Different Mixtures and Concentrations of Nutrients

\begin{tabular}{lccccc}
\hline $\begin{array}{c}\text { Nutrient } \\
\text { mixture }^{a}\end{array}$ & $\begin{array}{c}\text { Nitrogen } \\
(\mu \mathrm{g} / \mathrm{ml})\end{array}$ & $\begin{array}{c}\text { Optical density, } \\
100-T\end{array}$ & $10^{6} \times$ cells/ml & $\begin{array}{c}\text { Protein } \\
(\mu \mathrm{g} / \mathrm{ml})\end{array}$ & $\begin{array}{c}\text { Chlorophyll a } \\
(\mu \mathrm{g} / \mathrm{ml})\end{array}$ \\
\hline $\mathrm{F}$ & $3 \cdot 5$ & 52 & $1 \cdot 34$ & $9 \cdot 58$ & $0 \cdot 09$ \\
& 7 & 63 & $1 \cdot 26$ & $17 \cdot 77$ & $0 \cdot 44$ \\
& 14 & 68 & $1 \cdot 90$ & $37 \cdot 82$ & $2 \cdot 03$ \\
& 28 & 67 & $1 \cdot 85$ & $55 \cdot 73$ & $1 \cdot 52$ \\
& 56 & 59 & $1 \cdot 42$ & $37 \cdot 65$ & $2 \cdot 43$ \\
$\mathrm{~F}+\mathrm{SE}$ & 112 & 48 & $1 \cdot 60$ & $26 \cdot 99$ & $1 \cdot 20$ \\
& $3 \cdot 5$ & 65 & $1 \cdot 67$ & $22 \cdot 04$ & $1 \cdot 25$ \\
& 7 & 65 & $1 \cdot 69$ & $36 \cdot 30$ & $2 \cdot 48$ \\
& 14 & 73 & $1 \cdot 99$ & $38 \cdot 49$ & $2 \cdot 64$ \\
& 28 & 68 & $1 \cdot 81$ & $56 \cdot 31$ & $3 \cdot 20$ \\
$\mathrm{~F}+\mathrm{SE}+\mathrm{M}$ & 56 & 63 & $1 \cdot 74$ & $38 \cdot 60$ & $3 \cdot 27$ \\
& 112 & 48 & $1 \cdot 16$ & $39 \cdot 34$ & $2 \cdot 05$ \\
& $3 \cdot 5$ & 71 & $2 \cdot 66$ & $31 \cdot 73$ & $1 \cdot 11$ \\
& 7 & 75 & $2 \cdot 50$ & $33 \cdot 50$ & $1 \cdot 48$ \\
& 14 & 75 & $3 \cdot 00$ & $59 \cdot 25$ & $3 \cdot 30$ \\
& 28 & 62 & $1 \cdot 72$ & $64 \cdot 71$ & $4 \cdot 40$ \\
& 56 & 57 & $1 \cdot 10$ & $29 \cdot 40$ & $3 \cdot 95$ \\
$\mathrm{~F}+\mathrm{M}+\mathrm{V}$ & 112 & 48 & $1 \cdot 17$ & $39 \cdot 91$ & $2 \cdot 58$ \\
& $3 \cdot 5$ & 56 & $1 \cdot 45$ & $10 \cdot 17$ & $0 \cdot 56$ \\
& 7 & 69 & $1 \cdot 82$ & $15 \cdot 48$ & $0 \cdot 84$ \\
& 14 & 78 & $2 \cdot 25$ & $32 \cdot 77$ & $2 \cdot 11$ \\
& 28 & 66 & $1 \cdot 42$ & $61 \cdot 68$ & $2 \cdot 79$ \\
& 56 & 57 & $1 \cdot 26$ & $44 \cdot 15$ & $2 \cdot 53$ \\
& 112 & 49 & $1 \cdot 11$ & $28 \cdot 49$ & $2 \cdot 35$ \\
& 28 & 96 & $5 \cdot 58$ & $147 \cdot 46$ & $9 \cdot 88$ \\
\hline
\end{tabular}

${ }^{a}$ Abbreviations: F, fertilizer; SE, soil extract; M, micronutrients; V, vitamins.

The fertilizer Ferticros does not contain all the elements necessary for maximum microalgal growth, although it can be used as a source of nitrogen and phosphorus. 
The use of soil extract for marine microalgal growth in seawater is very common (Prakash and Rashid, 1968; Prakash et al., 1973). This soil extract can supply vitamins, micronutrients and, perhaps, certain other growth factors, acting besides as a chelating agent (Hoeffner and Manahan, 1980) because humic substances chelate ions of $\mathrm{Fe}, \mathrm{Ca}, \mathrm{Al}, \mathrm{Cu}$ and $\mathrm{Co}$, so that these ions are prevented from precipitating essential microalgal nutrients such as phosphate (Prakash et al., 1973); on the other hand, the involvement of humic substances in cellular metabolic processes is also a possibility (Prakash and Rashid, 1968).

We established the efficiency as the ratio between the nitrogen added to the culture medium and the protein nitrogen produced per culture. Maximum efficiency was obtained in the cultures with the mixture of $F+S E$ (Table 2).
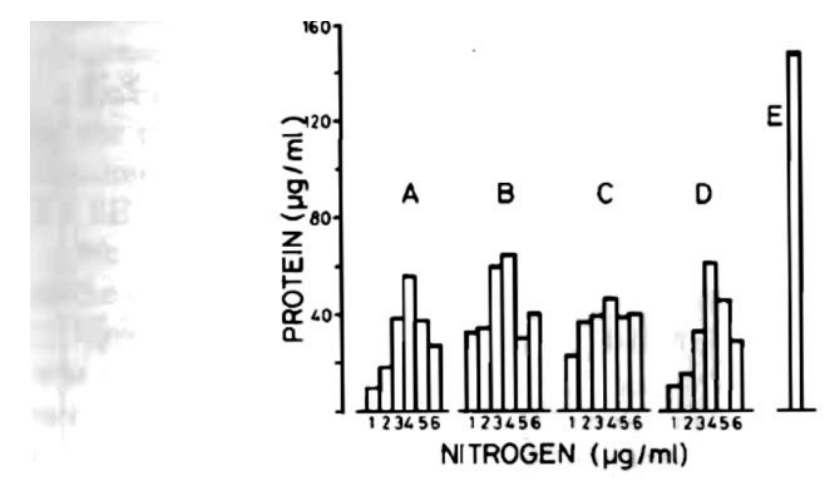

Fig. 3. Protein concentrations in cultures of $T$. suecica with different mixtures and concentrations of nutrients: A, fertilizer; B, fertilizer + soil extract; C, fertilizer + soil extract + micronutrients; D, fertilizer + micronutrients + vitamins; $\mathrm{E}$, control. Nitrogen contents $(\mu \mathrm{g})$ per $\mathrm{ml}$ of culture were: $1,3 \cdot 5 ; 2,7 ; 3,14 ; 4,28 ; 5,56 ; 6,112$.

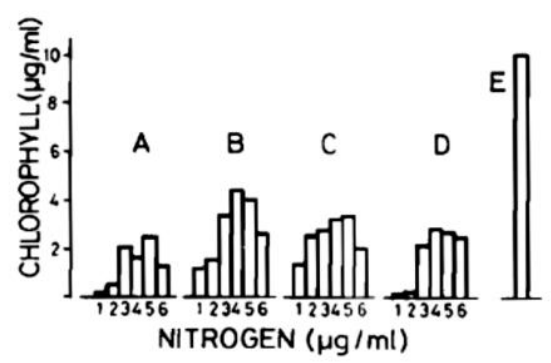

Fig. 4. Chlorophyll a concentrations in cultures of $T$. suecica with different mixtures and concentrations of nutrients: A, fertilizer; B, fertilizer + soil extract; $\mathrm{C}$, fertilizer + soil extract + micronutrients; D, fertilizer + micronutrients + vitamins; E, control. Nitrogen contents $(\mu \mathrm{g})$ per $\mathrm{ml}$ of culture were: $1,3 \cdot 5 ; 2,7 ; 3,14 ; 4,28 ; 5,56 ; 6,112$. 
TABLE 2

Economic Evaluation of T. suecica Culture Media with Different Mixtures and Concentrations of Nutrients

\begin{tabular}{|c|c|c|c|c|c|c|c|}
\hline $\begin{array}{l}\text { Nutrient } \\
\text { mixture }\end{array}$ & $\begin{array}{c}\text { Nitrogen } \\
(\mu \mathrm{g} / \mathrm{ml})\end{array}$ & $\begin{array}{r}10^{3} \times \text { cost } \\
(5 / 100 \text { litre })\end{array}$ & $\begin{array}{l}\text { Protein/100 lïtre } \\
(\mathrm{g})\end{array}$ & $\begin{array}{l}\text { Protein/S } \\
\text { (g) }\end{array}$ & $\begin{array}{c}\text { Efficiency } \\
(\%)\end{array}$ & $\begin{array}{c}10^{9} \times \text { cells/ } \\
100 \text { litre }\end{array}$ & $10^{12} \times$ cells $/ \mathrm{s}$ \\
\hline \multirow[t]{6}{*}{ F } & $3 \cdot 5$ & 0.73 & 1.0 & 1360 & 45 & 134 & 182 \\
\hline & 7 & 1.47 & 1.8 & 1224 & 41 & 126 & 85 \\
\hline & 14 & 2.94 & 3.8 & 1292 & 43 & 190 & 64 \\
\hline & 28 & 5.88 & $5 \cdot 5$ & 935 & 31 & 185 & 31.5 \\
\hline & 56 & 11.76 & $3 \cdot 7$ & 314 & 10 & 142 & 12 \\
\hline & 112 & $23 \cdot 52$ & $2 \cdot 7$ & 102 & $3 \cdot 8$ & 160 & 6.8 \\
\hline \multirow[t]{6}{*}{$\mathbf{F}+\mathrm{SE}$} & 3.5 & 0.79 & $2 \cdot 2$ & 2770 & 99 & 167 & 210 \\
\hline & 7 & 1.53 & $3 \cdot 6$ & 2373 & 82 & 169 & 110 \\
\hline & 14 & $3-00$ & $3 \cdot 8$ & 1283 & 44 & 199 & 66 \\
\hline & 28 & 6.47 & $5 \cdot 6$ & 947 & 32 & 181 & $30 \cdot 5$ \\
\hline & 56 & 11.82 & 3.8 & 326 & 11 & 174 & $14 \cdot 7$ \\
\hline & 112 & $23 \cdot 58$ & 3.9 & 166 & $5 \cdot 6$ & 116 & 5 \\
\hline \multirow[t]{6}{*}{$F+S E+M$} & 3.5 & $10 \cdot 91$ & $2 \cdot 2$ & 198 & 99 & 266 & 24 \\
\hline & 7 & 11.65 & $3 \cdot 3$ & 287 & 76 & 250 & 21 \\
\hline & 14 & $13 \cdot 12$ & 5.9 & 451 & 67 & 300 & 22 \\
\hline & 28 & 16.06 & $6 \cdot 4$ & 402 & 37 & 172 & 10 \\
\hline & 56 & 21.94 & $2 \cdot 9$ & 134 & $4 \cdot 8$ & 110 & 5 \\
\hline & 112 & 27.82 & $3-9$ & 143 & $5 \cdot 7$ & 117 & $4 \cdot 2$ \\
\hline \multirow[t]{6}{*}{$\mathrm{F}+\mathrm{M}+\mathrm{V}$} & 3.5 & $46 \cdot 41$ & $1-0$ & 21 & 45 & 145 & 3 \\
\hline & 7 & $47 \cdot 17$ & 1.5 & 33 & 35 & 182 & 4 \\
\hline & 14 & 48.65 & $3 \cdot 3$ & 67 & 37 & 222 & 4 \\
\hline & 28 & 51.59 & $6 \cdot 1$ & 119 & 35 & 142 & 3 \\
\hline & 56 & 57.47 & $4 \cdot 4$ & 77 & 12 & 126 & 2 \\
\hline & 112 & 68.82 & 2.8 & 41 & 4 & 111 & $1 \cdot 6$ \\
\hline Control & 28 & $2450 \cdot 00$ & 14.7 & 7 & 84 & 558 & 0.26 \\
\hline
\end{tabular}

${ }^{a}$ Abbreviations as in Table 1.

We carried out an economic evaluation, but only referred to the cost of the different chemical compounds of the different mixtures.

Maximum concentration of microalgal protein, expressed as $\mathrm{g} /$ dollar, was obtained with $\mathrm{F}+\mathrm{SE}$, with $2770 \mathrm{~g}$ of protein/dollar, at a nitrogen concentration of $3^{\prime} 5 \mu \mathrm{g} / \mathrm{ml}$. Maximum cellular density of $210 \times 10^{12}$ cells/dollar was obtained with the same mixture of $\mathrm{F}+\mathrm{SE}$ and at the same nitrogen concentration (Table 2). Comparing these data with the control, we obtained better economic results with $\mathrm{F}+\mathrm{SE}$ than with the control, the differences being up to 404 -fold in terms of protein/dollar and 810 -fold in terms of cells/dollar.

\section{Acknowledgements}

We thank Professor Dr B. Regueiro Varela for his interesting comments and Cros SA for their cooperation. This work was supported by a grant from Direccion General de Ordenacion Pes que ra, Ministerio de Agricultura, Pesca y Alimentacion, Madrid, Spain. 


\section{References}

1. Bayne BL. The biology of mussel larvae. Marine Mussels: Their Ecology and Physiology 1976:81-120.

2. Bradford MM. A rapid and sensitive method for the quantitation of microgram quantities of protein utilizing the principle of protein-dye binding. Anal Biochem 1976;72(1-2):248-54.

3. De Pauw N, Verboven J, Claus C. Large-scale microalgae production for nursery rearing of marine bivalves. Aquacult Eng 1983;2(1):27-47.

4. Fabregas $\mathrm{J}$, Herrero $\mathrm{C}$. Marine microalgae as a potential source of single cell protein (SCP). Appl Microbiol Biotechnol 1985;23(2):110-3.

5. Fabregas J, Abalde J, Herrero C, Cabezas B, Veiga M. Growth of the marine microalga tetraselmis suecica in batch cultures with different salinities and nutrient concentrations. Aquaculture 1984;42(3-4):207-15.

6. Fabregas J, Herrero C, Veiga M. Effect of oil and dispersant on growth and chlorophyll a content of the marine microalga tetraselmis suecica. Appl Environ Microbiol 1984;47(2):4457.

7. Fabregas J, Herrero C, Cabezas B, Abalde J. Mass culture and biochemical variability of the marine microalga tetraselmis suecica kylin (butch) with high nutrient concentrations. Aquaculture 1985;49(3-4):231-44.

8. Fabregas J, Herrero C, Abalde J, Cabezas B. Growth, chlorophyll a and protein of the marine microalga isochrysis galbana in batch cultures with different salinities and high nutrient concentrations. Aquaculture 1985;50(1-2):1-11.

9. Gonzalez-Rodriguez E, Maestrini SY. The use of some agricultural fertilizers for the mass production of marine algae. Aquaculture 1984;36(3):245-56.

10. Hoeffner SL, Manahan SE. Influence of coal humic acid on the growth of chlorella vulgaris algae. Journal of Environmental Science and Health - Part A Environmental Science and Engineering 1980;15(2):149-61.

11. Laing I, Utting S. The influence of salinity on the production of two commercially important unicellular marine algae. Aquaculture 1980;21:79-86.

12. Parsons TR, Strickland JDH. Particulate organic matter. III.I. pigment analysis. III.I.I. determination of phytoplankton pigments. J.Fish.Res.Board can. 1965;18:117-27.

13. Persoone G, Claus C. Mass culture of algae: A bottleneck in the nursery culturing of molluscs. Algae Biomass 1980:265-85.

14. Prakash A, Rashid MA. Influence of humic substances on the growth of marine phytoplankton: Dinoflagellates. Limnol Oceanogr 1968;13:598-606.

15. Prakash A, Rashid MA, Jensen A, Subba Rao DV. Influence of humic substances on the growth of marine phytoplankton: Diatoms. Limnol Oceanogr 1973;18(4):516-24.

16. Shelef G, Soeder CJ. Algae Biomass: Production and use 1980.

17. Soeder CJ. Massive cultivation of microalgae: Results and prospects. Hydrobiologia 1980;72(1-2):197-209.

18. Stein JR. Handbook of Phycological Methods: Culture Methods and Growth Measurements 1973.

19. Ukeles R. American experience in the mass culture of microalgae for feeding larvae of the american oyster crassostrea virginica. Algae Biomass 1980:287-306.

20. Walne PR. Culture of Bivalve Molluscs 1974. 